\title{
The retinal axon's pathfinding to the optic disk
}

\author{
Claudia A.O. Stuermer*, Martin Bastmeyer \\ Department of Biology, Developmental Neurobiology, University of Konstanz, 78457, Konstanz, Germany
}

\begin{abstract}
Retinal ganglion cell (RGC) axons travel in radial routes unerringly toward the optic disk, their first intermediate target in the center of the eye. The path of the RGC growth cone is restricted to a narrow zone subjacent to the endfeet of Müller glial cells and the vitreal basal lamina. The present survey indicates that RGC growth cones are guided by many molecular cues along their pathway which are recognized by receptors on their surface. Growth promoting molecules on Müller glial endfeet and in the basal lamina assist growth cones in maintaining contact with these elements. The repellant character of deeper retinal laminae discourages them from escaping the RGC axon layer. Cell adhesion/recognition proteins enable growth cones to fasciculate with preformed axons in their vicinity. It is still unclear whether the optic disk emits long range guidance components which enable the growth cones to steer toward it. Recent evidence in fish indicates the existence of an axonal receptor (neurolin) for a guidance component of unknown identity. Receptor blockade causes RGC axons to course in aberrant routes before they reach the disk. At the disk, axons receive signals to exit the retina. Contact with netrin 1 at the optic disk/nerve head encourages growth cones to turn into the nerve. This response requires the axonal netrin receptor DCC, laminin $1, \beta$ integrin and most likely the UNC5H netrin receptors which convert the growth encouraging signal into a repulsive one which drives growth cones into the nerve.
\end{abstract}

\section{Contents}

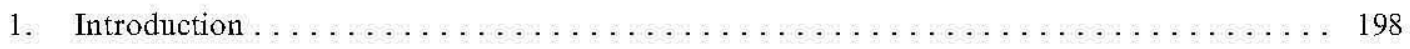

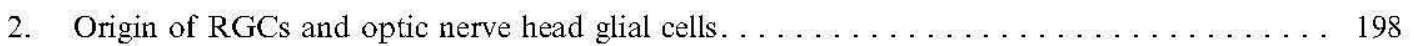

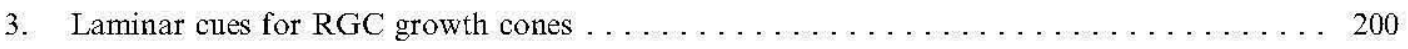

4. Effects of Müller glial cells, basal lamina, and extracellular matrix proteins on intraretinal

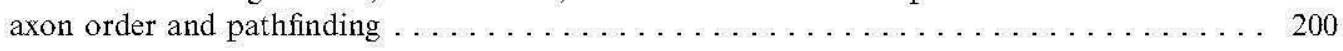

5. Directional cues in the optic fiber layer? . . . . . . . . . . . . . . . 201

6. Adhesion/recognition molecules and intraretinal axon guidance. . . . . . . . . . . 201

7. RGC axon pathinding to the optic disk in goldfish $\ldots \ldots \ldots \ldots \ldots \ldots \ldots \ldots \ldots$

\footnotetext{
Abbreviations: RGC, Retinal ganglion cell; IgSF, Immunoglobulin superfamily; CSPG, Chondroitin sulfate proteoglycan; DCC, Deleted in colon rectal cancer; RTK, Receptor tyrosine kinase; ECM, Extracellular matrix; NCAM, Neural cell adhesion molecule; CAM, Cell adhesion molecule; PSA, Polysialic acid; FGFR, Fibroblast growth factor receptor; RTPT, Receptor tyrosine phosphatase.

* Corresponding author.

E mail address: claudia.stuermer@uni konstanz.de (C.A.O. Stuermer).
} 
8. Ephrins and Eph receptors show position specific expression patterns across the retina .... 208

9. Growth cone navigation at the optic nerve head $\ldots \ldots \ldots \ldots \ldots \ldots \ldots \ldots \ldots$

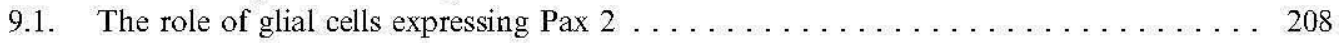

9.2. The role of netrin 1 and netrin receptors . . . . . . . . . . . . . . 209

9.3. ROBO and Slit family members are expressed in the retina. . . . . . . . . 210

10. Zebrafish mutants with intraretinal guidance defects. . . . . . . . . . . . . . 210

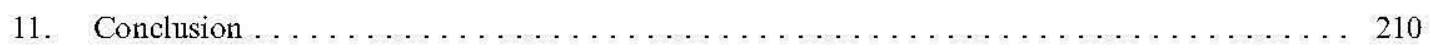

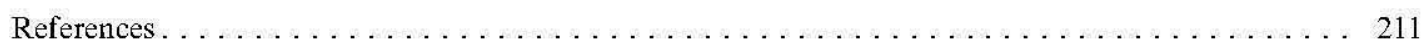

\section{Introduction}

The axons of the retinal ganglion cells (RGCs) connect the neural retina with the visual target centers in the mesencephalon, diencephalon, and telencephalon and establish synaptic connections that allow vision. The path of the RGC axons from the eye to their target brain structures is complex and contains critical regions where growth cones must take the correct pathways to gain access to their synaptic targets. The first of these critical areas occurs within the eye as soon as the ganglion cell differentiates and produces its growth cone. Within the eye, the path of the RGC growth cone is restricted to a narrow zone lying beneath the endfeet of the Müller glial cells (Fig. 1). The Müller cells are radial glial cells that originate in the retinal neuroepithelium, which gives rise to all retinal neurons. Once in this layer, the growth cone navigates towards the optic fissure and the later optic disk/ optic nerve head. Axons from dorsal, ventral, nasal, and temporal retina coalesce onto this one central structure to exit the eye. Here, they change their direction of growth from a centripetal, disk-directed route and enter the optic nerve (Fig. 1c). Thus, the optic disk/nerve head region represents the first intermediate target for the RGC axons on their journey to the synaptic target regions and therefore is expected to provide cues for growth cone steering to and across this region. That the optic disk/nerve head might play a central role in RGC axon guidance was first recognized by Ramon-Y-Cajal (1972), who suggested that this structure produces long range chemoattractive components for the guidance of axons. Such cues could account for the reliability with which RGC axons from all retinal positions navigate to the disk. To date, such long-range guidance components have not been identified. Instead, alternative guidance mechanisms were implicated in intraretinal growth cone navigation, as will be discussed in the following chapters. In fact, the optic disk/nerve head cells express many specific molecules. Among them is netrin-1, one of the first axon guidance molecules found to function as a chemoattractant in guiding commissural axons in radial routes in the spinal cord to and across the floor plate. Interestingly, many molecules participating in growth cone guidance in the spinal cord at the floor plate also occur in the retina (Fig. 2). This implies that molecular interactions of comparable complexity are operating in axon guidance at the floor plate and in the retina. Thus, as the function of the new protein family members are disclosed, the many elusive aspects of RGC growth cone navigation may be better understood.

The fact that RGC growth cones make pathway decisions and are able to steer in defined directions makes it clear that they navigate under the control of several cues and those presently under discussion will be considered in this review, with emphasis on studies addressing the RGC axon's growth/guidance in its natural or seminatural environment. A definition of the cellular elements that structure the axon pathway and schematics of their spatial arrangements are helpful for understanding how they influence the RGC growth cone (Fig. 1).

\section{Origin of RGCs and optic nerve head glial cells}

The eye and neural retina evolve as lateral evaginations of the embryonic diencephalic walls. They are connected to the forebrain by the optic stalk, a transitory structure that provides the substratum for the first RGC axons to extend from the retina to the diencephalon. The initial enlargement of the optic vesicle and eye cup is asymmetric with the optic stalk at its base, where the choroid fissure develops, an opening through which the first axons exit the eye. Mesenchymal cells invade the eye cup through the fissure and form the retinal artery. Later in development, the retina on either side of 


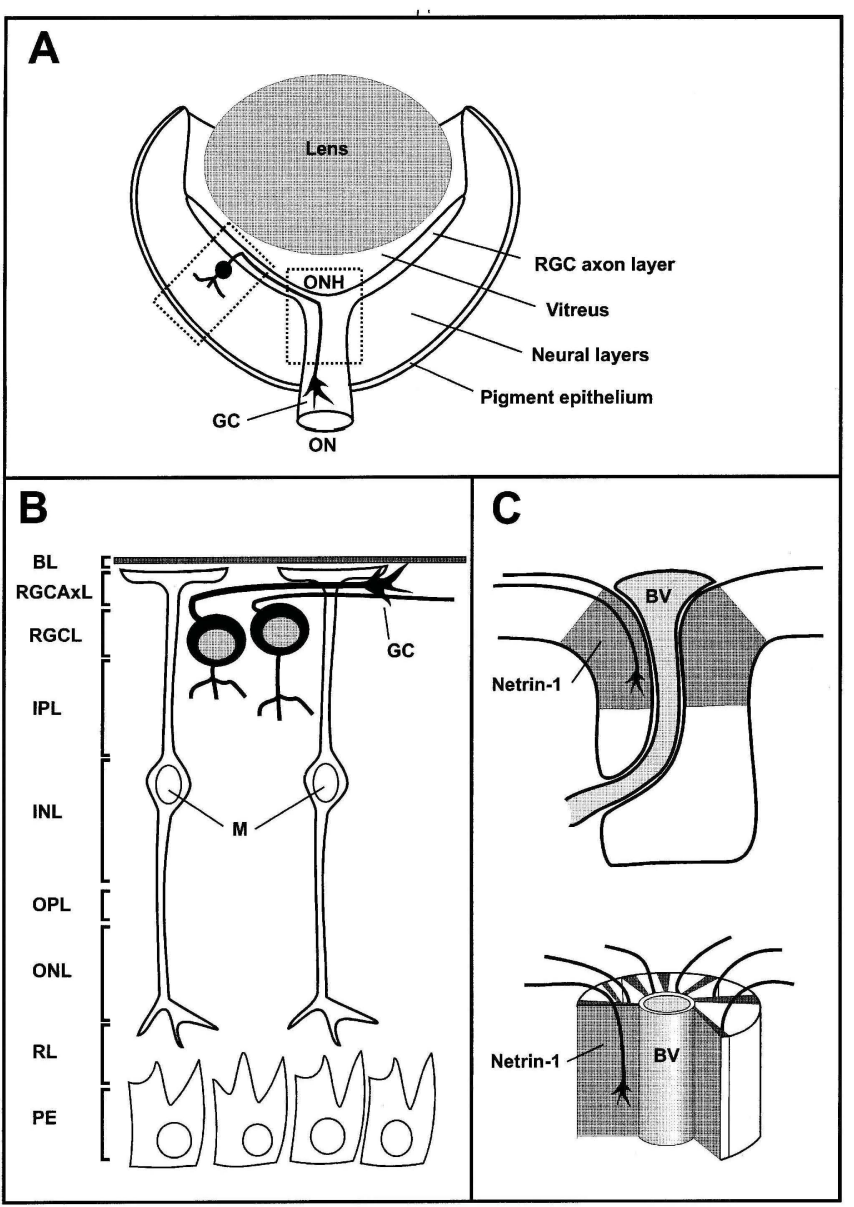

Fig. 1. The path of the RGC growth cone within the retina and into the optic nerve head. (A) Schematic representation of the developing eye featuring an individual RGC (black cell), the path of an axon (black line) and growth cone (GC) leaving the retina through the optic nerve head $(\mathrm{ONH})$ and growing into the optic nerve (ON). The RGC's dendrite is oriented towards outer retinal layers and the axon towards the inner limiting membrane (basal lamina, BL) which extends between the retina and vitreus. Upon contact with endfeet of neuroepithelial and later Muller glia cells (see B), the RGC axon bends to travel towards the optic disk/nerve head region in the cen ter of eye and undergoes another shift in orientation to exit the ret ina by growing along the surface of the optic nerve head glial cells. The grey oval structure represents the lens. The boxed regions are shown in detail in B and C, respectively. (B) Schematized cross sec tion through retina showing the spatial relationship of the RGCs (black cells) and their axons and growth cones (GC) in the optic fiber layer (OFL) with regard to Muller glial cells (M) and their end feet subjacent to the basal lamina (BL). The elongating RGC growth cone makes contact with and is guided by Muller glia endfeet, the basal lamina and preformed RGC axons. The retinal layers defined in many textbooks are indicated by the abbreviations commonly used: BL: basal lamina; RGCaxL: RGC axon layer; RGCL: retinal ganglion cell layer; IPL: inner plexiform layer; INL: inner nuclear layer; OPL: outer plexiform layer; ONL: outer nuclear layer; RL: receptor layer; PE: pigment epithelium. (C) Schematics of the optic nerve head region in a cross sectional (upper) and quasi 3 dimen sional view (lower figure). The greyish structure represents the retinal artery (BV). The grey domains are optic disk/nerve head glial cells which express netrin 1 . The RGC axons are guided by netrin 1 along the surface of the netrin 1 expressing glial cells. the fissure enlarges and fuses around the forming blood vessel and the exiting axons so that a circular structure, the optic disk, is formed. During the time of axon outgrowth, epithelial cells of the stalk give rise to the first optic nerve glial cells and to cells lining the fissure (Mcdonald et al., 1995) which are crucially involved in its closure. The behaviour of these cells is abnormal in mutants with defects in the expression of the transcription factor pax-2 with the consequence that in these mutants the fissure fails to close. In addition, the RGC axons fail to exit the eye or exhibit defects in the order in which they exit (see Section 9). When the fissure is closing, these cells are retained around the optic disk, extend into the optic nerve head, and contribute to guidance of axons into the optic nerve (see Section 9).

The retina itself originates from a neuroepithelial sheet which expresses pax-6. Six neuronal and one glial cell type emerge from this structure in a spatiotemporal pattern (reviewed in Goldowitz et al., 1996). There appears to exist a polarity across the thickness of retinal epithelium which contributes to the spatiotemporal pattern of neuronal and glial cell differentiation and to their strict laminar distribution. The first retinal cell type to differentiate is the retinal ganglion cell (RGC) whose somata occupy the most vitreal side of the neuroepithelial sheet, the prospective RGC layer. The first RGCs differentiate in proximity to the fissure so that the distance that the first RGC axons have to cover to reach the optic fissure is short. The retinal region where the first RGCs emerge is in the ventro-nasal aspect of the retina in fish (Laessing and Stuermer, 1996; Schmitt and Dowling, 1996), in the dorsotemporal retina in frogs and mammals (Grant and Rubin, 1980a, 1980b; Sidman, 1961), and directly dorsal to the fissure in birds (Halfter et al., 1985). These axons pioneer the path into the fissure and, unlike the later emerging growth cones, do not have preformed axons as guides. All RGC axons project toward the inner, i.e., vitreal aspect of the neuroepithelium where they contact the neuroepithelial endfeet and subsequently the endfeet of Müller glial cells which differentiate concurrently with the retinal neurons. A basal lamina (or inner limiting membrane) separates the glial endfeet from the vitreous and developing lens. In addition to polarity across the thickness of the retina, there is a striking centroperipheral gradient of retinal differentiation in the plane of the retinal neuroepithelium in all vertebrates. This is particularly evident in fish, where the retina differentiates in annuli and continues to grow by the addition of new neurons around the retinal circumference (see Section 7). Growth cones of younger, more peripheral RGCs find, in addition 
to Müller glial endfeet, preformed axons in their vicinity which they can follow to reach the disk/ optic nerve head.

Thus, the cellular elements and molecular cues which growth cones encounter and to which they respond via recognition proteins on their surface occur in the RGC axon layer, on Müller glial endfeet, on the basal lamina, on neighboring partner axons and at the optic fissure/disk and nerve head region (Fig. 1b). The subsequent paragraphs will review experiments addressing the role of these various elements during intraretinal axon guidance in fish, frogs, birds and mammals.

\section{Laminar cues for RGC growth cones}

When the RGC growth cones extend to the vitreal surface of the retinal neuroepithelium its dendrites develop in the opposite direction. While polarity across the thickness of the retina and an intrinsic polarity of the RGCs may underlie these decisions, molecular signals in the RGC's environment determine the course of the growth cone. During contact formation with neuroepithelial cell or Müller glial cell endfeet, the axon turns 90 degrees and becomes oriented toward the fissure (Holt, 1989). Before considering the cues which help the growth cone choose the appropriate direction, we will consider why they grow in the appropriate layer. This has been addressed in a series of tissue culture experiments in chick.

RGC growth cones originating from retinal explants exhibit a remarkable preference for the innermost retinal layer when retina cryosections are offered as a growth substrate (Stier and Schlosshauer, 1995). They avoid growth into deeper retinal layers which seem to possess non-permissive substrate properties for RGC axons. Accordingly, a preparation of Müller glial endfeet as substratum promoted quite extensive outgrowth, whereas a retinal strip from which the retinal fiber layer and glial endfeet were mechanically removed suppressed RGC growth on the retinal tissue (Stier and Schlosshauer, 1995). Moreover, when isolated RGCs were seeded onto cultures consisting almost entirely of retinal glial cell somata (obtained through complement-mediated cytolysis of neuronal cells), RGCs lying on glial cells produced dendritic processes but no significant axon extension (Bauch et al., 1998). Those lying next to glial cells extended axons but their growth cones collapsed upon contact with retinal glia (B. Schlosshauer, personal communication).

This supports the notion that Müller glial somata (but not their endfeet) have growth-inhibiting properties for RGC axons (yet not for RGC dendrites). These features could account for the non-permissive character of outer retinal layers for axons where Mül- ler glial somata and their proximal processes are located. Quite recent results suggest that retinal Müller glial cells, at least in vitro, synthesize ephrin-A5 (B. Schlosshauer, personal communication), a member of a large family of ligands for receptor tyrosine kinases (RTKs) of the Eph family (reviewed in Orioli and Klein, 1997). One major receptor of ephrin-A5 on $\mathrm{RGC}$ axons is the receptor tyrosine kinase Eph A3 (reviewed in Drescher et al., 1997). Eph A3 is involved in the RGC growth cone response to ephrin A5 (one of the A class ephrins) expressed in the optic tectum (Drescher et al., 1995), which manifests itself as a position-dependent repulsion of RGC axons.

If ephrin A5 is relevant for intraretinal axon guidance and for limiting RGC axon growth to the zone subjacent to the endfeet, it should be restricted to glial somata and the proximal portion of their processes and must not extend to the endfeet which promote axon growth (B. Schlosshauer, personal communication). Thus, by responding to repellent cues and growth-promoting components on Müller glial endfeet, the newly-formed RGC growth cone restricts its growth to a narrow zone above the RGC somata and below the glial endfeet and the vitreal basal lamina. Both components elicit vigorous growth of RGC axons in vitro (Halfter et al., 1987; Stier and Schlosshauer, 1995) and are therefore potential substrates for growth and guidance of RGC growth cones. According to some authors, the Müller glial endfeet form a continuous layer on the vitreal side of the developing retina (Holt, 1989) but there seem to be spaces between Müller endfeet where growth cones have access to the basal lamina (Easter et al., 1984; Ledig et al., 1999a) and to the numerous extracellular matrix molecules (ECM).

\section{Effects of Müller glial cells, basal lamina, and extracellular matrix proteins on intraretinal axon order and pathfinding}

The basal lamina overlying the retina is made up of collagen IV with which other extracellular matrix (ECM) proteins and proteoglycans are associated, such as laminin, nidogen, entactin, heparan-sulfate proteoglycans, perlecan and agrin, chondroitin-sulfate proteoglycans and other, unidentified proteins (Halfter, 1998). Laminin is certainly one of the most widespread ECM proteins with growth-promoting properties for a variety of neurons (reviewed in McKerracher et al., 1996; Luckenbill-Edds, 1997). The relevant receptors for laminin are integrins of the $\alpha 3 \beta 1-, \alpha 6 \beta 1-$, and $\alpha 5 \beta 1$-subtypes (reviewed in Reichardt and Tomaselli, 1991). RGCs extending axons in vitro on laminin as substrates are inhibited by antibodies against integrins (de Curtis and Reichardt, 1993) and fail to extend 
once integrin expression is downregulated. Studies of exposed brain preparations of Xenopus embryos employing a strategy for in vivo transfection of the RGCs have induced the expression of a dominantnegative form of $\beta$-integrin. RGCs expressing this mutant $\beta 1$ integrin form extend fewer processes than normal, but those axons that do extend follow the appropriate pathway in the eye and to the tectum (Lilienbaum et al., 1995). Thus, integrins markedly effect RGC axon growth. They may not be crucially involved in guidance to the disk, but recent results indicate a function of integrins and laminin-1 in growth cone steering out of the eye (see Section 8).

When the basal lamina, with or without the glial endfeet, is offered as substrate, RGC growth cones do not exhibit directionality (Halfter et al., 1987). Digestion of the basal lamina in chick embryos in vivo by injection of bacterial collagenase caused a disorganized pattern of the RGC axon trajectories in which individual axons acquired an undulated appearance. Still, axons did grow and did reach the optic fissure (Halfter, 1998). However, an additional quality of the basal lamina-associated ECM molecule chondroitin-sulfate proteoglycan (CSPG), which is considered to be growth-repellent for RGC axons (Snow et al., 1991), has been described in the rat retina. CSPG is initially distributed over the center of the rat retina but apparently recedes from central retinal regions just at the time when the first differentiating RGCs extend their axons. It is suggested that RGC growth cones move toward the optic fissure/optic disk because of the growth repellent CSPG in more peripheral locations. As more peripheral RGCs differentiate, CSPG progressively recedes towards the peripheral margin. Its function is envisioned as regulating the sequence and polarity of neuronal differentiation as well as forcing axons to elongate away from the periphery (Snow et al., 1991; Brittis et al., 1992; Brittis and Silver, 1995). Indeed, in retinae treated with enzymes that digest this proteoglycan, axons grow in random directions (Brittis et al., 1992). Although this is a quite compelling result, no such centroperipheral gradients of CSPG were found in chick (Halfter, 1998) or fish (unpublished results)

\section{Directional cues in the optic fiber layer?}

As explained in Section 1, a chemoattractant emerging from the fissure and later optic disk would neatly account for the oriented growth of RGC axons. Electron microscopic analysis of the early developing chick (Krayanek and Goldberg, 1981) and mouse retina (Silver and Sidman, 1980) demonstrated the existence of numerous extracellular spaces in the layer below glial endfeet and suggested the presence of preformed chan- nels (Bork et al., 1987) for the guided growth of RGC axons, serving as a pathway of least resistance (mechanical guidance) or representing a pathway paved with growth-supportive molecules. Preformed channels of centripetal orientation extending all the way to the fissure/disk, however, were not identified, and it seems rather unlikely that mechanical guidance (Halfter et al., 1985; Silver and Sidman, 1980; Krayanek and Goldberg, 1981) sufficiently accounts for the centripetal pathways of the RGC growth cones.

In Xenopus, if the eye is rotated by $180^{\circ}$ before RGCs extended their axons, many axon fascicles grow in circumferential instead of centripetal routes. Moreover, where an optic fissure has developed in ectopic positions (the dorsal retina), axons reach it via abnormal routes, exit, and follow the oculomotor nerve or other routes into the head mesenchyme. In these experiments, the fissure seems to exert a remarkable influence on direction of axon growth. Moreover, it allows axons to exit the retina in entirely abnormal regions (Grant and Rubin, 1980a).

Later experiments performed in chick to determine whether the disk exerts a long-range chemotropic effect on retinal growth cones failed to confirm such an influence. When an additional fissure was transplanted to a more peripheral location, axons of RGCs in positions peripheral to the transplant passed right through the transplant and toward the natural disk at the center of the retina. Furthermore, experiments involving transplantation of small retinal pieces in a 180-degreereverted orientation still resulted in oriented growth toward the disk. This in turn led to the suggestion that the retinal tissue in chick has a preferred axonal growth orientation which runs towards or away from the disk (Halfter, 1996). This was supported by the observation that axons exhibit orientation problems only when transplants are rotated $90^{\circ}$ degrees to the peripherocentral direction. This is consistent with the view that they have a preference for radial directions and was supported by another assay. In rats, RGC axons that were mechanically deflected grew in the direction of the retinal margin with growth velocities and morphologies indistinguishable from growth cones growing in the correct direction (Brittis and Silver, 1995). Therefore, it seems that in the embryonic rat and chick retina, directionality is not imparted on RGC growth cones by a diffusible substance released from the optic fissure. The outcome of these and earlier studies led to the conclusion that local rather than distant cues predominate in intraretinal axon guidance.

\section{Adhesion/recognition molecules and intraretinal axon guidance}

Aside from receptors for ECM components and 
ligands associated with glial endfeet, there is an impressively large number of cell adhesion/recognition molecules of various distinct protein families on the

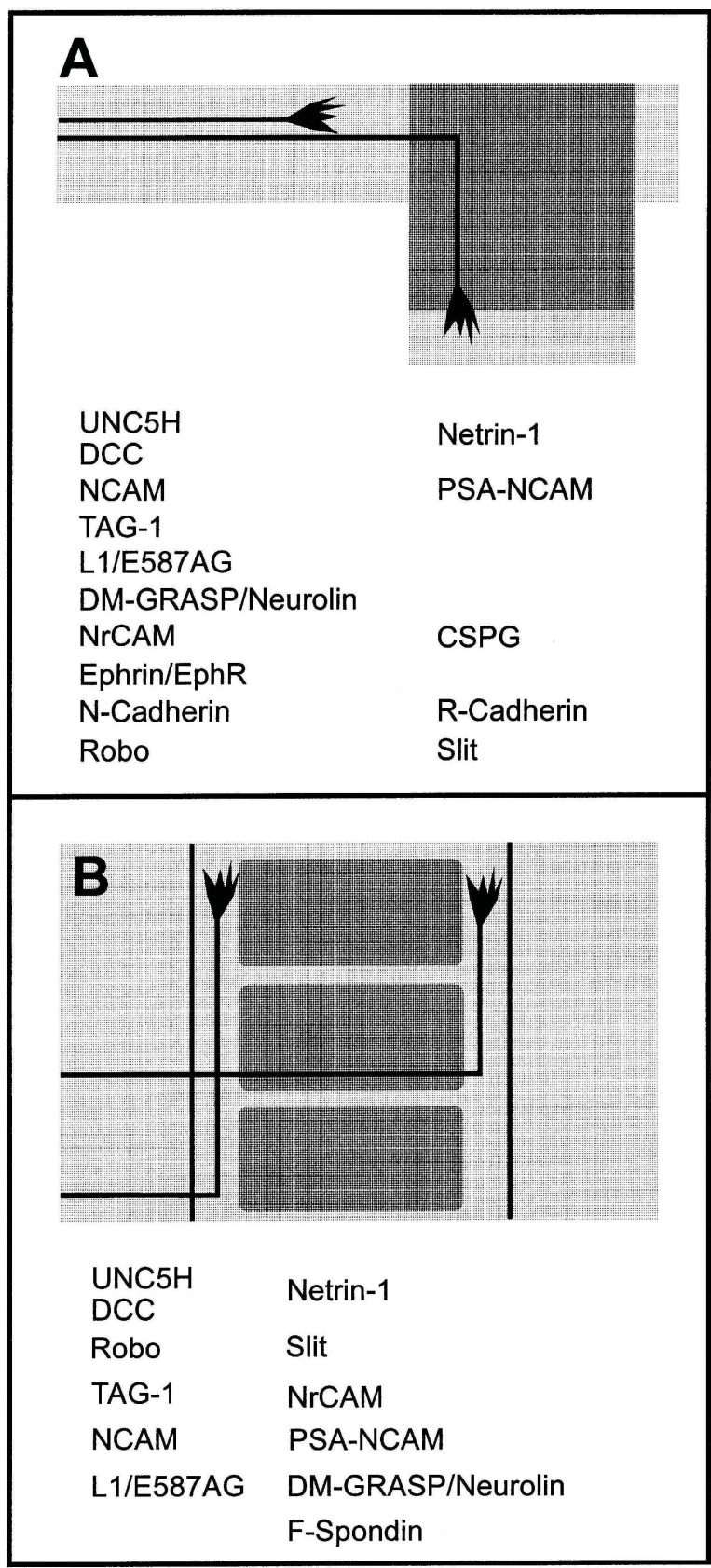

Fig. 2. Comparison of the path of RGC axons in the retina (A) and of commissural axons crossing the floor plate in the developing spinal cord (B). The optic nerve head region and floor plate cells are shown in dark grey, the axons and growth cones in black. RGC axons carry many surface recognition/receptor proteins for growth in the RGC axon layer and towards the optic nerve head and require optic nerve head associated cues to steer out of the eye into the optic nerve. In the spinal cord commissural axons course towards the floor plate where they chose longitudinal pathways on the ipsilateral side or after floor plate crossing on the contralateral side. Some of the relevant molecules expressed by RGC or commissural axons (left row) and by glial cells of the optic nerve head or floor plate cells (right row) are listed. surface of elongating RGC axons and the cellular elements which they contact.

Cadherins are known to contribute to axon growth via a $\mathrm{Ca}^{2+}$-dependent, homophilic binding mechanism (reviewed in Takeichi, 1990; Redies, 1997). RGC axons express at least three types of cadherins, N-cadherin, cadherin-6B and cadherin-7 (Matsunaga et al., 1988; Wöhrn et al., 1998), whereas R-cadherin is associated with glial cells in the optic nerve head and astrocytes in the optic nerve (Wöhrn et al., 1998). Ncadherin significantly affects RGC axon growth within the retina. When developing RGCs in Xenopus were transfected with a dominant negative form of $\mathrm{N}$-cadherin, RGCs failed to extend either axons or dendrites (Riehl et al., 1996). Thus, inhibition of $\mathrm{N}$-cadherin function impairs the formation of processes by developing RGCs.

The largest class of cell recognition molecules belong to the IgSF. They possess between 1-17 Ig-like domains and consist either of the Ig-domains only or of Ig-domains and structurally related fibronectin type III domains in variable number (reviewed in Brümmendorf and Rathjen, 1995). They may serve as guides for growth cones along other axons (fasciculation) and/or along cell surfaces such as Müller glia endfeet and basal lamina which express the relevant partner molecules or ligands. They may also contribute to guidance at the disk/nerve head, as specific IgSF CAMs are located at this structure (Fig. 2). It is becoming clear that these IgSF cell surface recognition/adhesion proteins are quite versatile compounds undergoing multiple interactions with other members of the same family, with ECM components and with guidance molecules of restricted expression. Rather than having overlapping and redundant functions, these proteins may have multiple and perhaps distinct functions during RGC axon pathfinding, as was recently shown in the spinal cord (reviewed in Stoeckli and Landmesser, 1998; Guthrie, 1999).

NCAM and members of the L1 subgroup of IgSF CAMs are found on elongating axons in all vertebrates, from fish to mammals (reviewed in Brümmendorf and Rathjen, 1995). Blockage of their function in retina organ cultures of chick and rat embryos impairs growth cone elongation and fasciculation but also interferes with their response to directional cues. L1blocked RGC growth cones in rats were observed to grow aberrantly at right angles to the fascicle track laid down by preceding axons (Brittis et al., 1995). NCAM-blocked axons in chick failed to exit the retina and instead continued to grow on the contralateral side (Thanos et al., 1984; Pollerberg and Beck-Sickinger, 1993). As NCAM is on both Müller glial endfeet and the extending axons (Brittis and Silver, 1995), anti-NCAM antibodies presumably interfere with growth cone contact to both these structures. The 
highly polysialated form of NCAM (PSA-NCAM) is located on RGC axons in chick (Schlosshauer et al., 1984) and is found to be enriched on cells at the optic disk region in embryonic Xenopus (Holt and Harris, 1993) and adult goldfish (M. Marx and M. Bastmeyer, unpublished results). It has been proposed that polysialation counteracts adhesive interactions between CAMs to allow exploratory movements of the growth cone and to enhance its responsiveness to signals in the environment (reviewed in Rutishauser and Landmesser, 1996; Kiss and Rougon, 1997). Whether PSANCAM contributes to RGC axon guidance in the retina has not yet been tested.

It has been suggested that both NCAM and L1 undergo lateral interactions with the fibroblast growth factor receptor (FGFR), a receptor tyrosine kinase, in the plane of the membrane and induce intracellular signalling cascades through the FGFR tyrosine kinase domains. The FGFR is expressed on RGC axons from the earliest stages of development (Cirillo et al., 1990; Wanaka et al., 1991). It is believed that the FGFR is recruited by L1 L1 as well as NCAM NCAM interactions and thus serves as a partner in CAM-mediated signal transduction (reviewed in Viollet and Doherty, 1997). Antibodies against FGFR and agents blocking steps in FGFR signal transduction had quite dramatic effects on the course of the RGC axons (Brittis et al., 1996), which turned into the periphery of the retina instead of joining forerunners in their path to the fissure. Thus, the FGFR may serve as the secondary but essential partner in CAM-mediated RGC axon guidance. The fact that axons are severely deflected from their pathway towards the disk may suggest that the FGFR is also involved in transducing directional information beyond the L1- and NCAM-mediated adhesion signals. Moreover, the FGFR was reported to interact with N-cadherin (Doherty and Walsh, 1996), but how this affects RGC axon growth has not, to our knowledge, been experimentally tested.

Both RGC axons and glial endfeet also carry on their surface the IgSF CAM, NrCAM (de la Rosa et al., 1990; Grumet et al., 1991). NrCAM undergoes homophilic binding as well as multiple heterophilic interactions with molecules including other IgSF CAMs (contactin/F3/F11, axonin-1/TAG-1, neurofascin), proteoglycans and laminin (reviewed in Grumet, 1997). Blockage of NrCAM function in the chick retina in vivo seems to provoke significant defects, in that RGC axons fail to exit through the fissure and are deflected by it (E. Pollerberg, S. Henke-Fahle, personal communication). Of the many molecular interactions NrCAM is involved in, it is not known which causes these pathfinding errors. RGC axons express at least some of the IgSF CAMs with which NrCAM interacts, i.e. axonin-1/TAG-1 (Ruegg et al., 1989; Wolfer et al., 1994) and contactin/F3/F11 (Rathjen et al., 1987).
These in turn bind to ECM molecules and interact with proteins, such as receptor tyrosine phosphatases (RTPTs), belonging to other structurally related superfamilies (Cervello et al., 1996; Peles et al., 1997). Recent results indicate the existence of a still unidentified ligand for the axonally expressed receptor tyrosine phosphatase (RTPT) CRYP $\alpha$ in the basal lamina and, more specifically, on Müller glia endfeet. Antibodies against CRYP $\alpha$ as well as AP-tagged soluble CRYP $\alpha$ constructs which compete with the natural ligand in binding to the receptor, affect RGC growth cone morphology and lead to a reduction of axon elongation (Ledig et al., 1999b). From this it is expected that IgSF proteins are involved in the formation of dynamic molecular complexes and thereby modulate RGC axon pathfinding but how do they regulate growth cone steering along the intraretinal pathway is not presently known.

A better understanding of its role in intraretinal axon pathfinding has recently been obtained for DCC (Deleted in Colon rectal Cancer), another member of the IgSF which supports axon outgrowth (Pierceall et al., 1994). DCC's prime function is that of a receptor and co-receptor for netrin-1 (Keino-Masu et al., 1996), which is associated with the optic disk/optic nerve head (discussed in Section 9.2).

A function as receptor or co-receptor has also been attributed to the IgSF member neurolin, which represents, at least by sequence homologies and its predicted structure, the fish homolog of DM-GRASP/ SC1/BEN (Burns et al., 1991; Tanaka et al., 1991; Pourquie et al., 1992; Laessing et al., 1994). Antibodies against DM-GRASP reduced the length of chick RGC axons elongating along other axons by $25 \%$ but had no effect on the directionality of the axon (Pollerberg and Mack, 1994). The erroneous pathways of neurolin-blocked axons in fish suggest that neurolin participates in RGC axon guidance and leads to discussion of guidance components still unidentified in nature

that assist RGC growth cones in maintaining their optic disk-directed path (below).

\section{RGC axon pathfinding to the optic disk in goldfish}

Fish RGC axons exhibit an unusual spatiotemporal expression pattern of IgSF proteins which closely correlates with RGC axon growth. This growth pattern will be briefly explained before functional aspects are discussed. The visual system of several classes of fish, including the goldfish, grows continuously throughout life in synchrony with the overall growth of the animal (Raymond, 1986). The fish retina possesses an annular growth zone around its entire peripheral margin where all cell types, including RGCs, required to build up new retina are generated (Johns, 1977). When new 
RGCs extend axons, they fasciculate with young axons from neighboring new RGCs and together with axons from the preceding $\mathrm{RGC}$ generation, travel towards the optic disk (Fig. 3), enter the optic nerve head and pass through the optic nerve into the optic tectum (Scholes, 1979; Easter et al., 1981, 1984; Stuermer and Easter, 1984). This growth results in a highly organized intraretinal fascicle pattern resembling the spokes of a cartwheel with the optic disk at its center. It also leads to an order determined by the age of axons in the optic nerve.

These young growing axons express a number of cell surface molecules, including the E587 antigen, a member of the L1 subfamily (Vielmetter et al., 1991; Giordano et al., 1997), neurolin, the apparent homolog of
DM-GRASP/SC-1/BEN (Paschke et al., 1992, Laessing et al., 1994), the high molecular forms of NCAM (Bastmeyer et al., 1990), M802 antigen, detected by an antibody against a cell surface protein (Stuermer et al., 1992), and TAG-1, which is expressed by nasal axons only (Lang et al., 1999).

The known growth promoting and homo- and heterophilic binding functions of their avian and mammalian homologs suggested that these IgSFCAMs in the fish retina mediate selective fasciculation so that new RGC axons reach the optic disk simply by following forerunners. The fact that the IgSF proteins underlay a strict spatiotemporal regulation guarantees that growth cones choose the more superficially located axons of recent generations as substrates for their

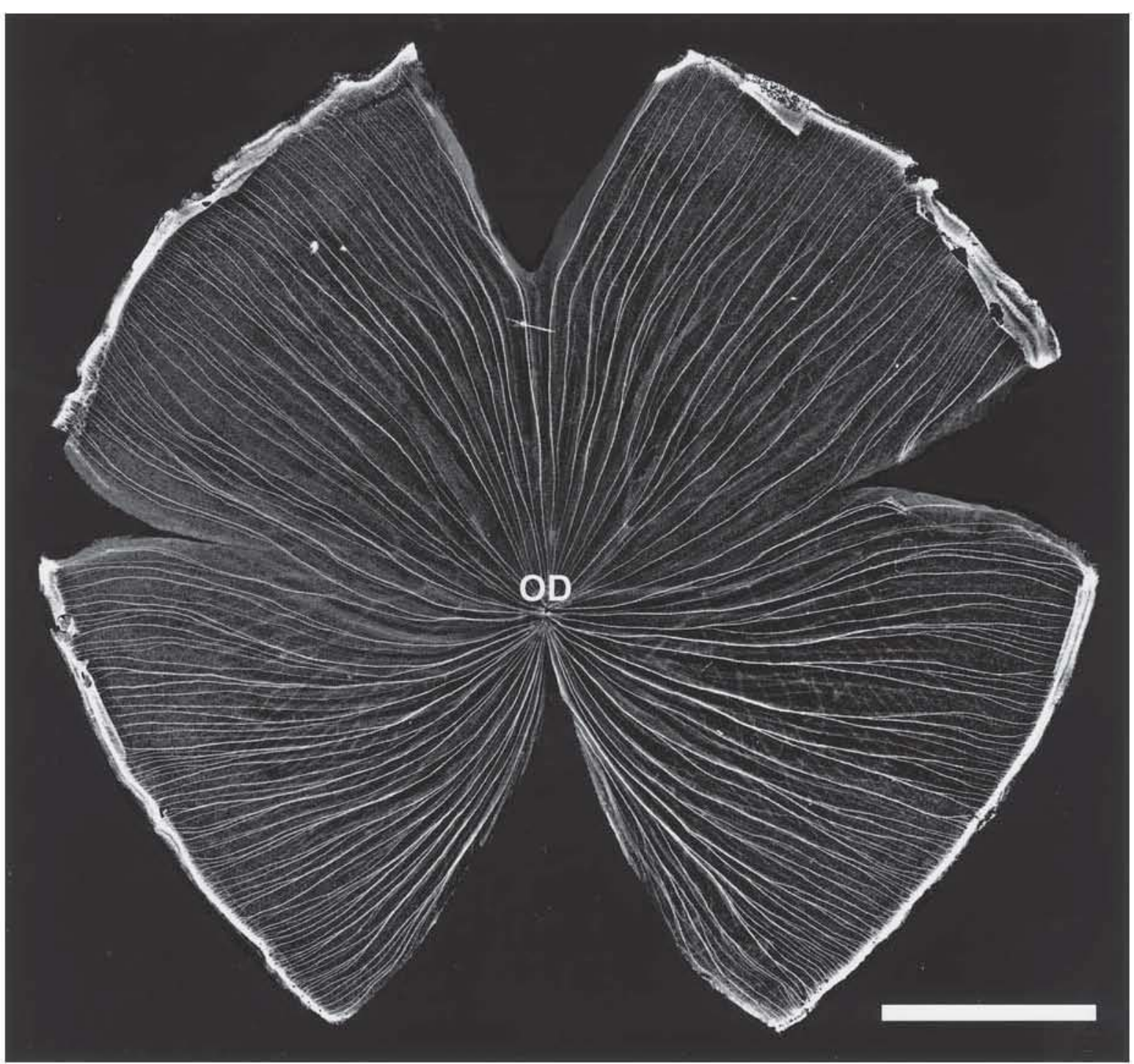

Fig. 3. The path of young RGC axons in the normal goldfish retina. Growing RGC axons are visualized in a retinal whole mount with anti bodies against neurolin. RGC axons derived from recently born RGCs at the retinal margin are associated in fascicles and course in centripetal pathways to the optic disk (OD). Scale bar, $1 \mathrm{~mm}$. (Kindly provided by C. A. Leppert.) 
elongation. This mechanism mediates selective fasciculation of young axons not only within the retina but also in the optic nerve where young RGC axons coalesce into one coherent bundle at the ventral extreme of the fish optic nerve.

Tissue culture experiments with immunopurified

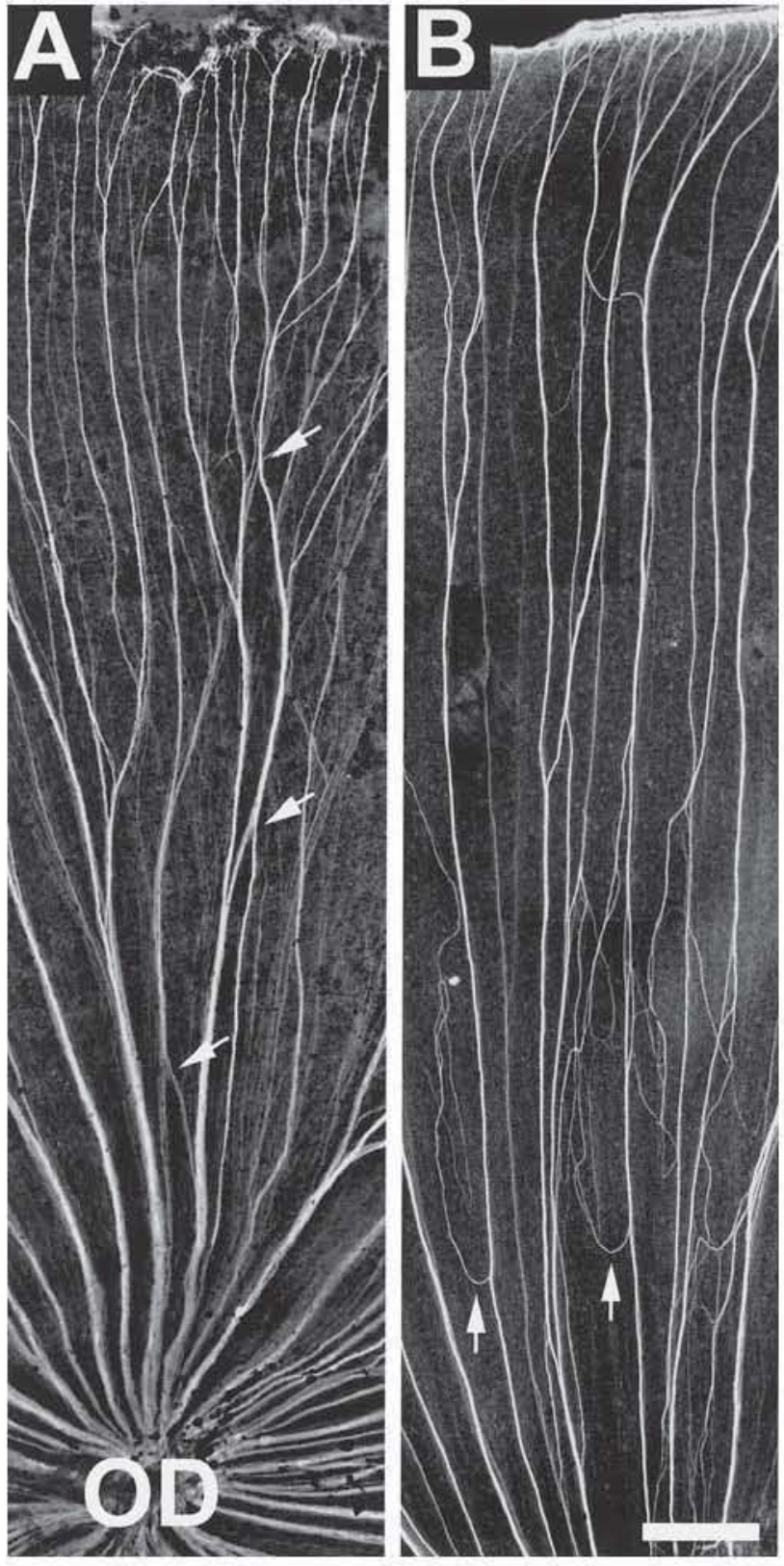

Fig. 4. The path of young RGC axons in the goldfish retina, after repeated injections of E587 Fabs (A) and neurolin Fabs (B). (A) Blockage of the L1 like E587 antigen expressed on the surface of young axons causes defasciculation of the fascicles (arrows), which reach the optic disk (OD) and exit the eye in spite of the disordered fascicles. Depicted is a segment of the dorsal retina. (B) Blockage of neurolin expressed on the surface of young growing axons causes severe pathway mistakes. Before they reach the disk bundles the axons turn 180 degrees (arrows), err through interfascicle territories and lose orientation altogether. Scale bar, $200 \mu \mathrm{m}$.
E587 antigen, RGC axons and various antibodies confirmed that this L1-like protein has growth-promoting substrate properties, mediates fasciculation and accelerates the velocity of the growth cones (Bastmeyer et al., 1995). The same assays applied to neurolin identified none of these properties (Ott et al., 1998; Leppert et al., 1999), but in vivo antibody pertubation experiments suggest that neurolin guarantees directed growth to the disk (Figs. 4 and 5). These in vivo experiments utilize the rapid growth of the eyes in wellnourished fish. Over a period of ten weeks, such juvenile goldfish double the diameter of their retinae, and generate roughly 50,000 new RGCs (Bastmeyer et al., 1995). During this period, Fab fragments of either a polyclonal anti-E587 antigen antiserum (E587 Fabs) or of an anti-neurolin antiserum (neurolin Fabs) are injected into the vitreous twice a week and bind to the surfaces of axons expressing the respective proteins.

Repeated injection of neurolin Fabs into the eyes of growing fish prevents many young RGC axons from reaching the optic disk (Ott et al., 1998). Small groups of axons depart from their fascicle of origin at a distance from the optic disk, turn $180^{\circ}$ or in full circles and apparently lose orientation altogether (Figs. 4 and 5). The misrouted axons end somewhere between the fascicle pathways as if they ultimately gave up growth. The formation of such errant axon trajectories can be seen directly in observations of labeled and neurolin Fab-treated growth cones in isolated and living retina (Fig. 6), where they depart from their parent fascicle, turn, and migrate through interfascicle regions with a $70 \%$ reduction of their growth velocity. This indicates that the substrate properties of interfascicle regions are far less growth promoting than the intrafascicle pathway. However, as seen with young RGC axons growing in the presence of E587 Fabs, growth outside of fascicles does not necessarily lead to highly erroneous routes and loss of orientation. In retinae exposed to E587-Fabs (Figs. 4 and 5), fasciculation of axons from neighboring new RGCs at the margin is delayed, crossing of axons is frequent and the width of fascicles near the disk is markedly increased (Bastmeyer et al., 1995). Still, axons do arrive at the disk, enter into the optic nerve head and into the optic nerve. Here, however, they fail to form one coherent bundle and are instead scattered throughout the nerve (Ott et al., 1998). This then, suggests that neurolin Fabs but not E587 Fabs impair the growth cone's ability to read directional cues in its environment. Experiments using monoclonal anti-neurolin antibodies which recognize an epitope in either neurolin Ig domain 1, 2 or 3, have shown that Ig domain 2 is crucially involved in the proposed receptor function of neurolin (Leppert et al., 1999). Neurolin may thus function as a receptor or part of a receptor complex involved in the perception of an 
axon guidance component with directional information for the advancing growth cone.

This obviously requires a ligand (or ligands) either within the fascicle pathway (but not in interfascicle territories) or emanating from the disk. The fact that neurolin-blocked axons turn away from the disk before reaching it leads to speculation that the postulated guidance component has an axon repellent function causing an avoidance response by axons as they approach the disk. This in turn implies that the function of neurolin is to guarantee growth of axons into and through the repellent territory around the optic disk. The search for the neurolin ligand(s) is complicated by the fact that neurolin blockage by antibodies deflects RGC axons from their disk-directed course most markedly in the dorsal half of the retina (Ott et al., 1998; Leppert et al., 1999). RGC axons in the ventral retina steer unerringly towards the disk although they are labeled by neurolin antibodies and the injected neurolin Fabs as strongly as axons of the dorsal retina. A similar effect became apparent after injections of E587 Fabs, which cause axon defasciculation mainly in the dorsal retina (Ott et al., 1998). Both neurolin and E587 Ag are therefore suspected to interact with other proteins providing position-specific identity to dorsal and ventral retinal cells. The interacting proteins could be specific ephrins and Eph receptors, known to be differentially expressed across the retina.

It has been demonstrated that Eph $\mathrm{B} 2$ interacts with L1 in that it phosphorylates the L1 intracellu-
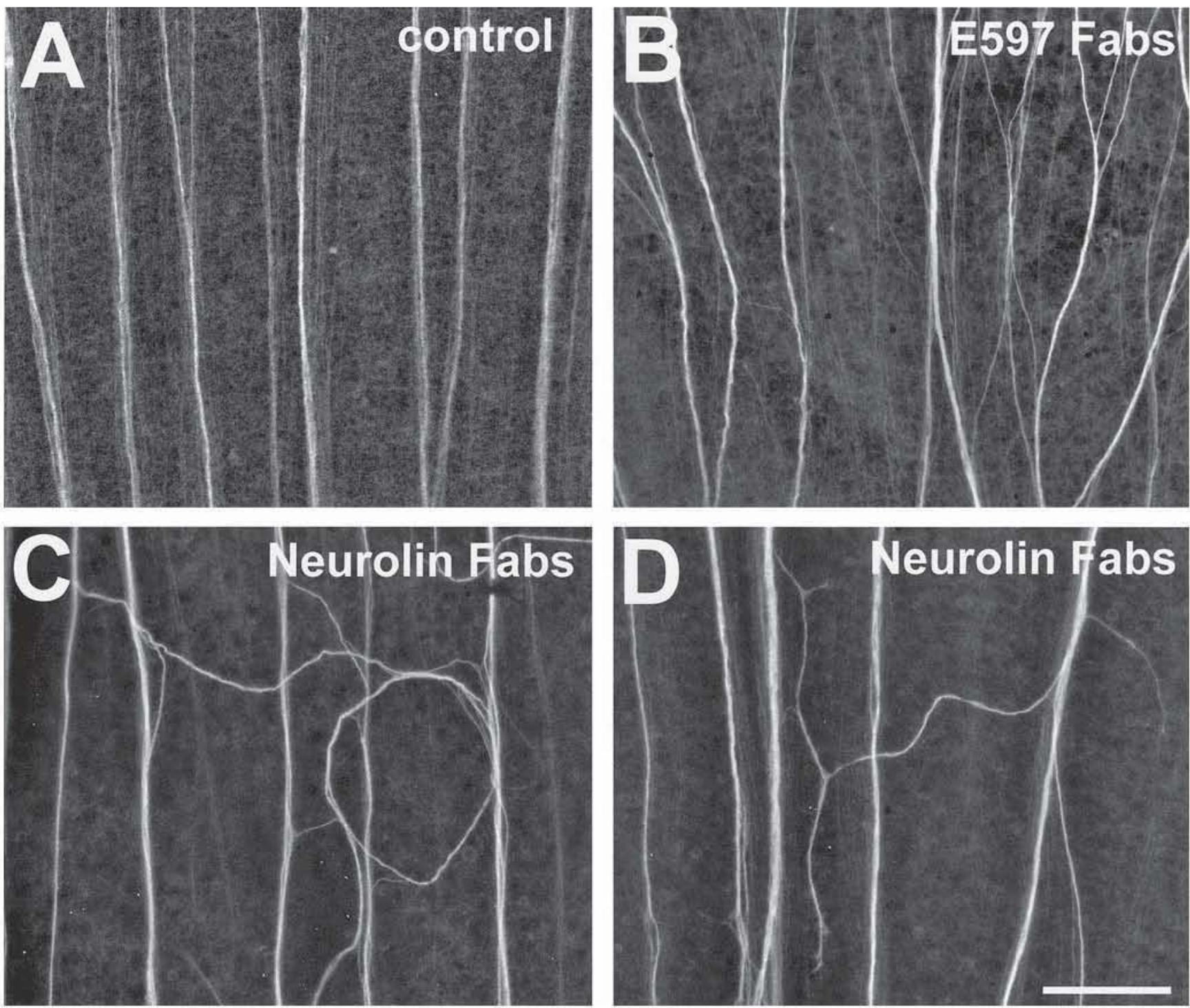

Fig. 5. Effects of E587 Fabs and neurolin Fabs on the order of young RGC axons. (A) Young RGC axons are associated in orderly fascicles on their path to the optic disk in control retinae. (B) When treated by E587 Fabs the fascicle order deteriorates and axons cross interfascicle terri tories to join any fascicle they encounter. (C, D) Neurolin Fabs cause highly aberrant axonal routes such as loops and circles, or let aberrant axons end in interfascicle territories. Scale bar, $100 \mu \mathrm{m}$. 
lar domain (Zisch et al., 1997). It thereby regulates fasciculation and axon growth, perhaps by mediating the recruitment of intracellular signalling proteins that bind tyrosine phosphorylated motifs or by influencing L1 interactions with cytoskeletal elements (reviewed in Burden-Gulley et al., 1997). As Eph B2 expression is high in ventral but low in dorsal retina (mouse: Henkemeyer et al., 1996; chick:
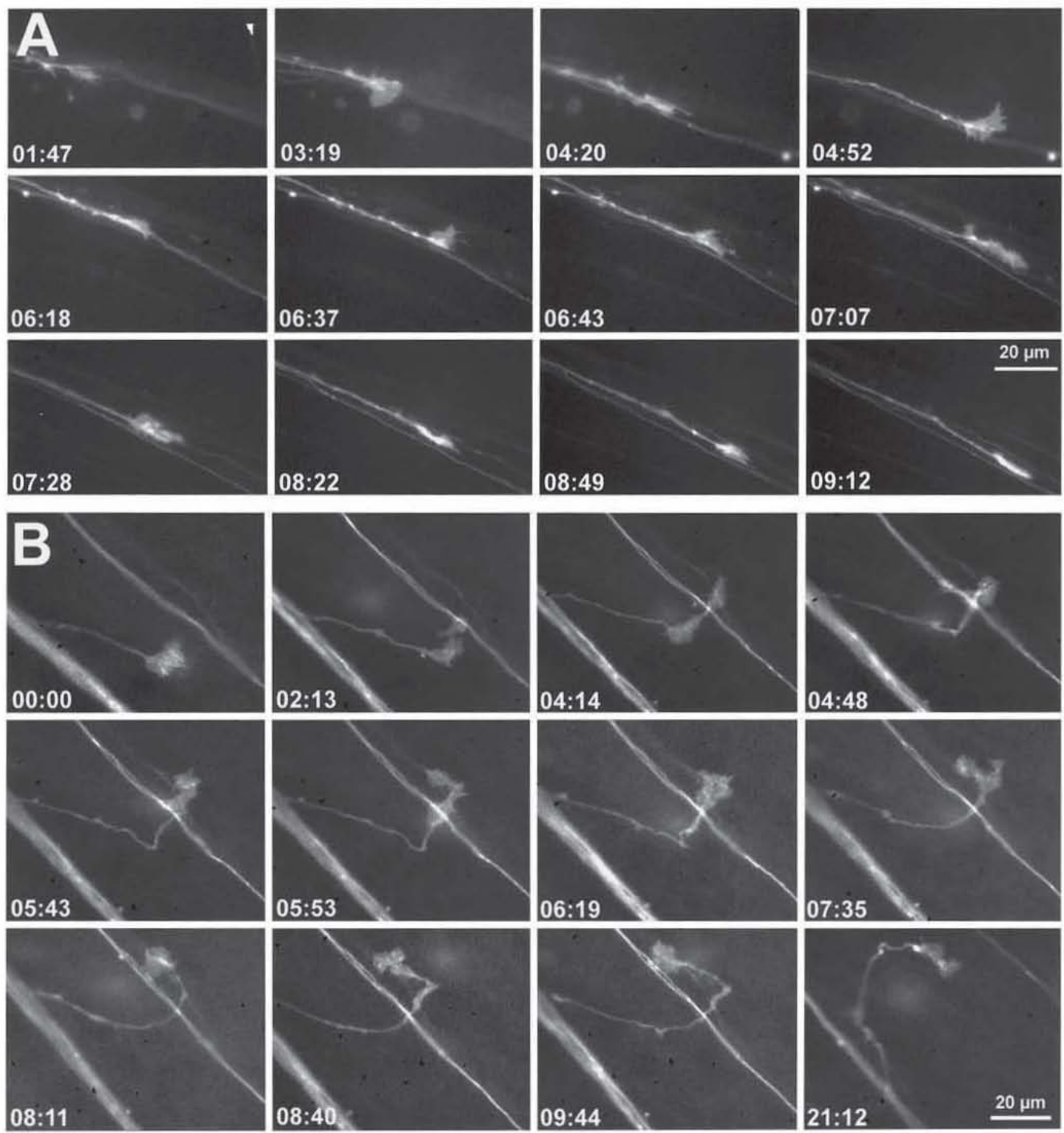

Fig. 6. Behavior of living RGC growth cones in control retinae and under the influence of neurolin Fabs. RGC growth cones were labeled with the fluorescent dye diO and observed in a living retinal wole mount preparation with videomicroscopy. (A) In control retinae, growth cone grow straight towards the optic disk in association with other labeled axons of the same fascicle. (B) In the presence of Fabs, the growth cone departs from the fascicle track laid down by other young axons, turns back into the direction of the retinal margin but hardly makes progress in its aber rant path and finally ceases its growth. The time elapsed between images is indicated in the left hand corner and given in hours and minutes. The optic disk is to the right. 
Holash and Pasquale, 1995; fish: H. Ott, E. Pasquale, U. Drescher, and C.A.O. Stuermer, unpublished), it seems possible that this uneven distribution leads to a differential phosphorylation state of L1 or the L1-like E587 antigen, which in turn may result in dorsal/ventral differences in axon fasciculation through molecular signalling pathways that remain to be explored. Whether such interactions occur between neurolin and Eph/ephrin family members is not known.

Members of other protein families including other IgSF CAMs can also be envisioned as interacting partners. It has recently been discovered that TAG-1 is differentially expressed in the fish retina. Its expression is high in the nasal retinal half and low in the temporal retinal half (Warren et al., 1999; Lang et al., 1999). A similar uneven distribution along the dorso-ventral dimension might also occur with other IgSF CAMs.

\section{Ephrins and Eph receptors show position-specific expression patterns across the retina}

The ephrins and Eph receptor tyrosine kinases represent the largest class of proteins that exhibit a position-specific distribution across the retina. In general, Eph receptor expression is often complementary to the distribution of its corresponding ligand subclass, suggesting that these receptors and their ligands define boundaries in the embryo and/or are relevant for interacting neuronal populations such as RGC axons and the visual target centers (reviewed in Drescher et al., 1997; O'Leary and Wilkinson, 1999; O'Leary et al., 1999).

Aside from results discussed in Sections 3 and 7, there is no direct evidence in support of the idea that positional marker molecules such as the Eph-receptors/ ephrins determine intraretinal axon guidance. However, opposing intraretinal gradients of receptors and ligands of A and B subclasses suggest further roles for the Eph family in the retina beyond their proposed role in lamina formation in the retina and the development of a retino-tectal map.

Eph B2 expression is high in ventral but low in dorsal retina and ephrin B2, which binds to Eph B2, shows the opposite distribution (Gale et al., 1996). In the mouse, Eph A3 expression levels are high in the temporal retina and low in the nasal retina. Ephrin A5, which binds to Eph A3, is high in the nasal retina and low in the temporal retina.

In the retina of chick embryos, ephrin B1 and Eph A7 show a dorsal to ventral gradient which later develops in a step gradient with a sharp line between dorsal expression domains and ventral retina (Sefton and Nieto, 1997). Another interesting pattern that relates to centroperipheral progression of RGC differentiation is displayed in the chick retina by Eph B5, which shows a radial gradient complementary to axon outgrowth similar to that of CSPG (Sefton and Nieto, 1997). The ligand of Eph B5 is not known to date (Sefton and Nieto, 1997).

Compelling expression patterns of Eph receptors and ephrins are also evident in zebrafish. In the retina of $24 \mathrm{~h}$ old embryos (before RGCs begin to differentiate), ephrin A5 (L4) is found in a region which later becomes nasal retina (Brennan et al., 1997), and is present at $30 \mathrm{~h}$ when the first cluster of RGCs in the nasal retina extend their axons (Laessing and Stuermer, 1996; Burrill and Easter, 1994). Eph A7 (ZDK1) is expressed in the lens and in the temporal half of the retina in the $48 \mathrm{~h}$ embryo (Taneja et al., 1996). Eph A4 (rtk1) is not expressed in the eye but in the diencephalon, and, in the $24 \mathrm{~h}$ embryo, in the optic recess and later in the proximal portion of the optic nerve head ( $\mathrm{Xu}$ et al., 1996). As was explained in the beginning of this review and will be discussed in the following Section, this region is crucial for the steering of RGC axons out of the eye.

Although information on possible functions of Eph receptors and their ligands during intraretinal axon guidance is not available at present, the patterned distribution of these proteins indicates that they may contribute to the growth behavior of RGC axons. This likewise applies to the various molecules in their intraretinal path displaying a patterned distribution in the developing retina (for an extensive review see Jean et al., 1998). This includes a variety of homeobox genes and transcription factors which determine cell fate regionalization of the retina and affect ephrin $\mathrm{B}$ and Eph B class protein expression (Perron et al., 1999; Schulte et al., 1999).

\section{Growth cone navigation at the optic nerve head}

\subsection{The role of glial cells expressing Pax-2}

The developing forebrain structures, especially the eye cup and optic stalk, display distinct expressional territories with regard to Pax-2 and Pax-6 (reviewed in Macdonald and Wilson, 1996). Perturbance of the expression domains of Pax-6 and Pax-2, which define the retina proper versus optic nerve/tract regions (Walther and Gruss, 1991; Nornes et al., 1990) leads to an impairment of the growth cone's ability to pass from retinal territories into the optic nerve head. Pax proteins constitute a family of transcription factors which possess a DNA binding domain, the paired box, and are involved in the regulation of many aspects during early development (reviewed in Stuart et al., 1994). Pax-6 expression territories define the retina and most of the eye structures except the lens, the cornea, and 
the fissure/optic nerve head region (Walther and Gruss, 1991; Mcdonald et al., 1995). Pax-2 expression is restricted to cells of the optic stalk, and later optic nerve, and to cells lining the fissure, which later form the optic disk/nerve head (Nornes et al., 1990; Mcdonald et al., 1995).

Mutant mice deficient in Pax-2 deficient exhibit extension of the pigmented retina into the optic stalks and failure of the fissure to close (Keller et al., 1994). Non-closing fissures called coloboma have been observed as congenital defects in humans. They are now known to be a consequence of Pax-2 deficiencies in humans, mice, and fish (Sanyanusin et al., 1995; Torres et al., 1996; Mcdonald et al., 1995). In zebrafish embryos, the optic nerve head glial cells and optic nerve astrocytes are identified by their expression of noi (no isthmus), a teleost pax-2 homolog (Mcdonald et al., 1995). As has been observed in fish lacking noi expression, the defective optic nerve head glial cells fail to properly arrange around the RGC axons (Mcdonald et al., 1995).

Aside from failure of the glial cells to promote closure of the fissure, further abnormalities were noted in Pax-2 mutants. In man, RGC axons have difficulty leaving the eye, resulting in optic nerve hypoplasia (reduced size) and aberrant intraretinal RGC axon growth (Sanyanusin et al., 1995). In zebrafish embryos, defects occur in the order of RGC axons leaving the eye (Mcdonald et al., 1995). All these defects have more recently also been observed in netrin-1 knock-out mice (Deiner et al., 1997), indicating that these problems may result, at least in part, from altered netrin-1 expression of the optic nerve head glial cells.

\subsection{The role of netrin-1 and netrin receptors}

The netrins are secreted and extracellular matrixbound guidance molecules that show some sequence homology to the short arm of laminin (Serafini et al., 1994). They are of particular relevance at the midline floorplate (Kennedy et al., 1994; Serafini et al., 1996) which harbors directly or in its vicinity a significant number of axon guidance cues (reviewed in Colamarino and Tessier-Lavigne, 1995; Stoeckli and Landmesser, 1998). Netrin-1 is expressed by optic nerve head glial cells and localized on the surface of these cells in fish (Strähle et al., 1997; Lauderdale et al., 1997), frogs (de la Torre et al., 1997) and mammals (Deiner et al., 1997). The picture that arises from the analysis of mammals lacking Pax-2 and of netrin-1 knock out mice suggests that netrin-1 produced by optic disk/ optic nerve head glial cells provides guidance for RGC axons, helps RGC axons enter into the nerve head and nerve, and prevents their errant and continued growth within the retina (Deiner et al., 1997). Netrin-1 seems to exert its influence on RGC axons through a con- tact-mediated mechanism rather than through longrange attraction. RGC growth cones travel unerringly toward the optic nerve head in netrin-1 knock out mice. To be able to respond to netrin- 1 , RGC axons require DCC, one of the netrin receptors presently known (Fazeli et al., 1997). The RGC axons in DCC null mutant mice exhibit the same pathfinding errors in netrin deficient mice (Deiner et al., 1997).

As in the floor plate, where crossing and non-crossing axons adopt new pathways after contact with floor plate cells that express netrin-1 (Fig. 2), RGC axons require signals to pass through the optic nerve head into the optic nerve proper (Höpker et al., 1999). This may involve a mechanism which reverses the contact dependent effect of netrin-1 on the growth cones. One way of achieving such a reversal is through modulation of the intracellular cAMP concentration (Ming et al., 1997). In tissue culture experiments with Xenopus RGC axons, growth cones respond to netrin-1 application by turning towards the netrin-1 source (de la Torre et al., 1997), showing that netrin-1 exerts a chemoattractive influence on Xenopus RGC axons in vitro. This effect is DCC dependent. Netrin-1/DCC signalling across the RGC growth cones elevates intracellular cAMP concentration (Ming et al., 1997; de la Torre et al., 1997). Counteracting this elevation causes RGC growth cones in vitro to turn away from a netrin-1 source (de la Torre et al., 1997). In vitro, laminin-1 was implicated in preventing the netrin-1induced increase in cAMP leading to a reversal of the growth cone response. A small laminin-1 peptide (YIGSR) was sufficient to obtain this effect. The observation that the netrin-1-dependent growth cone response is influenced by laminin-1 (and thus by signalling through $\beta$ integrins, as part of the laminin receptor) led to experiments to determine whether the same could occur in vivo. Application of this peptide during RGC axon growth in vivo prevented the growth of axons into the optic nerve head (Höpker et al., 1999). The authors argue that laminin-1 is limited to the vitreal surface of the retina and is thus near the optic nerve head only at its inception, where growth cones turn away from the vitreal surface to leave the retina, whereas netrin-1 is expressed throughout the optic nerve head. They propose a local modulatory influence (via cAMP levels) of laminin-1 on the netrinDCC-dependent signalling pathway so as to expel growth cones from the retina and thereby encourage their growth into the optic nerve head (Höpker et al., 1999).

Growth cone behavior in this region may be regulated in an even more sophisticated manner. RGC axons express not only the netrin-1 receptor DCC (responsible for interpreting netrin-1 as an attractant or growth-encouraging ligand) (Fazeli et al., 1997). They also synthesize UNC5H netrin receptor types (Leo- 
nardo et al., 1997). Elegant experiments have shown that DCC and UNC5H receptors cooperate in eliciting in the growth cone an aversive reaction to a netrin-1 source (Hong et al., 1999). In fact with DCC present, the intracellular domain of UNC5H receptors is sufficient to change the turning response of the growth cone towards a netrin- 1 source into an aversive reaction. It is believed that netrin binding to the receptors can cause direct interaction between the intracellular domains of DCC and UNC5H proteins, which then activate intracellular signaling cascades (perhaps via cAMP or in a parallel pathway) to bring about a response opposite to that produced by netrin binding to DCC alone (Hong et al., 1999; Bashaw and Goodman, 1999). As developing RGC axons also express DCC and UNC5H receptors (Leonardo et al., 1997), an attractive hypothesis is that growth cone contact with netrin-1 at the optic nerve head first encourages growth into this netrin-1 rich region. During passage, the growth cone's responsiveness may be converted to repulsion, helping the growth cone to move along. This could potentially be achieved by recruiting UNC5H receptors into the complex consisting of netrin-1 and DCC (Bashaw and Goodman, 1999).

\subsection{ROBO and Slit family members are expressed in the retina}

As indicated, the optic nerve head and RGC axons express additional receptor ligand pairs known to participate in axon guidance at the floor plate. In addition to netrin-1, the floor plate expresses proteins of the Slit family and both crossing and non-crossing axons have ROBO type receptors (Brose et al., 1999). ROBO receptors are IgSF proteins (Kidd et al., 1998) and ROBO-receptor interaction with Slit proteins results in growth cone repulsion (Kidd et al., 1999). Slit proteins and ROBO receptors were also recently identified in the rodent visual system (Yuan et al., 1999). There are three Slit proteins in mammals Slit 1,2 and 3. Slit 1 and 2 mRNAs are localized in the prospective RGC layer of the embryonic eye. Slit 3 mRNA is found in the lens and pigment epithelium. Its presence in the lens epithelium is interesting in light of recent findings showing that molecules synthesized by these cells cause collapse of RGC growth cones in vitro (Ohta et al., 1999). It is conceivable that molecules being secreted by the lens epithelium bind to the vitreal basal lamina and thus affect RGC growth cones in vivo. This may apply to other ECM components including F-spondin which is expressed in the developing lens (Higashijima et al., 1997). This ECM protein contributes to guidance of axons at the floor plate (Burstyn-Cohen et al., 1999), but whether it affects RGC axons remains to be explored.

Slit 2 mRNA is also expressed by cells of the optic nerve head (Holmes et al., 1998) and by optic nerve glial cells (Yuan et al., 1999). ROBO 1 mRNA is present in the forming RGC layer. As slit proteins can bind to ROBO 1 (and ROBO 2), a role in RGC axon guidance is not only conceivable but very likely. Moreover, by their restricted expression pattern across retinal layers Slit/ROBO interactions possibly contribute to the development of retinal cytoarchitecture.

From this perspective, and with increasingly more ligand receptor interactions being discovered, new insights may be obtained into the functions of these molecules in RGC axon pathfinding.

\section{Zebrafish mutants with intraretinal guidance defects}

New information on determinants of retinal axon guidance has been obtained from zebrafish mutants identified in large scale sceens (Haffter and NüssleinVolhard, 1996). The generation of hundreds of zebrafish mutants and analysis of RGC axon pathways resulted in the identification of two strains with severe intraretinal axon pathway defects. These are chameleon (con) and bashful (bal). In con mutants, RGC axons often do not exit the eye but instead grow along the equator of the eye in an anterior and/or posterior direction and fail to converge on the optic nerve head (Karlstrom et al., 1996). As con mutants have severe midline defects in axon pathfinding outside of the eye, defects in the expression of molecules required for midline crossing may also be responsible for the failure of RGC axons to navigate toward the optic nerve head. Unfortunately, con mutants are embryonic lethal, so that extended studies of their phenotype at later stages cannot be performed. The other mutant, bashful (bal), exhibits defects in the timely differentiation of RGCs in the temporal retina, and some have quite erroneous axon trajectories (Karlstrom et al., 1996). The axons do, however, exit the eye eventually and project towards the brain, where they often grow falsely into the forebrain and back into the ipsilateral tectum. To date, the defective molecule(s) have not yet been identified.

\section{Conclusion}

In this survey, which covers a only small fraction of the work in this area, we have discussed the role of a dozen or so families of cell surface molecules whose members are believed to function in intraretinal pathfinding. Not addressed in this review are intracellular signalling cascades which are activated by receptor 
ligand interactions. These intracellular signalling cascades affecting the cytoskeleton and growth cone behavior are just beginning to be elucidated (see for instance Mueller, 1999) and are of general importance, not only for intraretinal growth cone pathfinding. We have alluded to additional cues which may participate in growth cone guidance without giving proof that they do so. Moreover, further molecular components are envisioned to exist but have not yet been identified. Despite extensive research carried out over a century, we do not have a satisfying understanding of intraretinal growth cone guidance. On the other hand, we observe the breathtaking speed of the discovery of molecular networks affecting growth cone navigation. This gives reason for optimism that the cellular/molecular framework for the guided growth of axons in distinct regions of the developing brain including the eye will be understood.

We are impressed by the progress made in the recent years concerning growth cone steering at the midline in worms, flies and vertebrates. The same molecules involved there are also present in the developing visual system. This suggests that similar mechanisms are operating here and also implies that questions left open in this review will be answered in the very near future.

\section{References}

Bashaw, G.J., Goodman, C.S., 1999. Chimeric axon guidance recep tors: the cytoplasmic domains of slit and netrin receptors specify attraction versus repulsion. Cell 97,917 926.

Bastmeyer, M., Ott, H., Leppert, C.A., Stuermer, C.A.O., 1995. Fish E587 glycoprotein, a member of the L1 family of cell adhesion molecules, participates in axonal fasciculation and the age related order of ganglion cell axons in the goldfish retina. J. Cell Biol 130,969976 .

Bastmeyer, M., Schlosshauer, B., Stuermer, C.A.O., 1990. The spatiotemporal distribution of N CAM in the retinotectal path way of adult goldfish detected by the monoclonal antibody D3. Development 108, 299311.

Bauch, H., Stier, H., Schlosshauer, B., 1998. Axonal versus dendritic outgrowth is differentially affected by radial glia in discrete layers of the retina. J. Neurosc 18, 17741785.

Bork, T., Schabtach, E., Grant, P., 1987. Factors guiding optic fibers in developing Xenopus retina. J. Comp. Neurol 264, 147158.

Brennan, C., Monschau, B., Lindberg, R., Guthrie, B., Drescher, U., Bonhoeffer, F., Holder, N., 1997. Two Eph receptor tyrosine kinase ligands control axon growth and may be involved in the creation of the retinotectal map in the zebrafish. Development 124,655664 .

Brittis, P.A., Canning, D.R., Silver, J., 1992. Chondroitin sulfate as a regulator of neuronal patterning in the retina. Science 255,733 736.

Brittis, P.A., Lemmon, V., Rutishauser, U., Silver, J., 1995. Unique changes of ganglion cell growth cone behavior following cell ad hesion molecule perturbations: a time lapse study of the living retina. Mol. Cell. Neurosci 6, 433449.

Brittis, P.A., Silver, J., 1995. Multiple factors govern intraretinal axon guidance: a time lapse study. Mol. Cell. Neurosci 6, 413 432.

Brittis, P.A., Silver, J., Walsh, F.S., Doherty, P., 1996. Fibroblast growth factor receptor function is required for the orderly projec tion of ganglion cell axons in the developing mammalian retina. Mol. Cell. Neurosci 8, 120128.

Brose, K., Bland, K.S., Wang, K.H., Arnott, D., Henzel, W., Goodman, C.S., Tessier Lavigne, M., Kidd, T., 1999. Slit proteins bind robo receptors and have an evolutionarily conserved role in repulsive axon guidance. Cell 96, 795806 .

Brummendorf, T., Rathjen, F., 1995. Cell Adhesion Molecules 1: Immunoglobulin Superfamily. Academic Press, London.

Burden Gulley, S.M., Pendergast, M., Lemmon, V., 1997. The role of cell adhesion molecule L1 in axonal extension, growth cone motility, and signal transduction. Cell Tissue Res 290, 415422.

Burns, F.R., Von Kannen, S., Guy, L., Raper, J.A., Kamholz, J., Chang, S., 1991. DM GRASP, a novel immunoglobulin super family axonal surface protein that supports neurite extension. Neuron 7, 209220.

Burrill, J.D., Easter, S.S.J., 1994. Development of the retinofugal projections in the embryonic and larval zebrafish (Brachydanio rerio). J. Comp. Neurol 346, 588600.

Burstyn Cohen, T., Tzarfaty, V., Frumkin, A., Feinstein, Y., Stoeckli, E., Klar, A., 1999. F Spondin is required for accurate pathfinding of commissural axons at the floor plate. Neuron 23, 233246.

Cervello, M., Matranga, V., Durbec, P., Rougon, G., Gomez, S., 1996. The GPI anchored adhesion molecule F3 induces tyrosine phosphorylation: involvement of the FNIII repeats. J. Cell Sci 109,699704

Cirillo, A., Arruti, C., Courtois, Y., Jeanny, J.C., 1990. Localization of basic fibroblast growth factor binding sites in the chick embryonic neural retina. Differentiation 45, 161167.

Colamarino, S.A., Tessier Lavigne, M., 1995. The role of the floor plate in axon guidance. Annu. Rev. Neurosci 18, 497529.

de Curtis, I., Reichardt, L.F., 1993. Function and spatial distribution in developing chick retina of the laminin receptor alpha 6 beta 1 and its isoforms. Development 118, 377388 .

de la Rosa, E.J., Kayyem, J.F., Roman, J.M., Stierhof, Y. D., Dreyer, W.J., Schwarz, U., 1990. Topologically restricted appear ance in the developing chick retinotectal system of Bravo, a neural surface protein: experimental modulation by environmen tal cues. J. Cell Biol 111, 30873096.

de la Torre, J.R., Hopker, V.H., Ming, G.L., Poo, M.M., Tessier Lavigne, M., Hemmati Brivanlou, A., Holt, C.E., 1997. Turning of retinal growth cones in a netrin 1 gradient mediated by the netrin receptor DCC. Neuron 19, 12111224.

Deiner, M.S., Kennedy, T.E., Fazeli, A., Serafini, T., Tessier Lavigne, M., Sretavan, D.W., 1997. Netrin 1 and DCC mediate axon guidance locally at the optic dise: loss of function leads to optic nerve hypoplasia. Neuron 19, 575589 .

Doherty, P., Walsh, F.S., 1996. CAM FGF receptor interactions: a model for axonal growth. Mol. Cell Neurosci 8, 99111.

Drescher, U., Bonhoeffer, F., Muller, B.K., 1997. The Eph family in retinal axon guidance. Curr. Opin. Neurobiol 7, 7580.

Drescher, U., Kremoser, C., Handwerker, C., Loschinger, J., Noda, M., Bonhoeffer, F., 1995. In vitro guidance of retinal ganglion cell axons by RAGS, a $25 \mathrm{kDa}$ tectal protein related to ligands for Eph receptor tyrosine kinases. Cell 82, 359370.

Easter, S.S.J., Bratton, B., Scherer, S.S., 1984. Growth related order of the retinal fiber layer in goldfish. J. Neurosci 4, 21732190.

Easter, S.S.J., Rusoff, A.C., Kish, P.E., 1981. The growth and organ ization of the optic nerve and tract in juvenile and adult goldfish. J. Neurosci 1,793811.

Fazeli, A., Dickinson, S.L., Hermiston, M.L., Tighe, R.V., Steen, R.G., Small, C.G., Stoeckli, E.T., Keino Masu, K., Masu, M., Rayburn, H., Simons, J., Bronson, R.T., Gordon, J.I., Tessier 
Lavigne, M., Weinberg, R.A., 1997. Phenotype of mice lacking functional Deleted in colorectal cancer (Dcc) gene. Nature 386, 796804.

Gale, N.W., Holland, S.J., Valenzuela, D.M., Flenniken, A., Pan, L., Ryan, T.E., Henkemeyer, M., Strebhardt, K., Hirai, H., Wilkinson, D.G., Pawson, T., Davis, S., Yancopoulos, G.D., 1996. Eph receptors and ligands comprise two major specificity subclasses and are reciprocally compartmentalized during embry ogenesis. Neuron $17,919$.

Giordano, S., Laessing, U., Ankerhold, R., Lottspeich, F., Stuermer, C.A.O., 1997. Molecular characterization of E587 antigen: an axonal recognition molecule expressed in the goldfish central ner vous system. J. Comp. Neurol 377, 286297.

Goldowitz, D., Rice, D.S., Williams, R.W., 1996. Clonal architecture of the mouse retina. Prog. Brain Res $108,315$.

Grant, P., Rubin, E., 1980a. Ontogeny of the retina and optic nerve in Xenopus laevis. Part II: Ontogeny of the optic fiber pattern in the retina. J. Comp. Neurol 189,671 698.

Grant, P., Rubin, E., 1980b. Disruption of optic fibre growth follow ing eye rotation in Xenopus laevis embryos. Nature 287, 845848 .

Grumet, M., 1997. Nr CAM: a cell adhesion molecule with ligand and receptor functions. Cell Tissue Res 290, 423428.

Grumet, M., Mauro, V., Burgoon, M.P., Edelman, G.M., Cunningham, B.A., 1991. Structure of a new nervous system gly coprotein, Nr CAM, and its relationship to subgroups of neural cell adhesion molecules. J. Cell Biol 113, 13991412.

Guthrie, S., 1999. Axon guidance: starting and stopping with slit. Curr. Biol 9, R432 435.

Haffter, P., Nusslein Volhard, C., 1996. Large scale genetics in a small vertebrate, the zebrafish. Int. J. Dev. Biol 40, 221227.

Halfter, W., 1996. Intraretinal grafting reveals growth requirements and guidance cues for optic axons in the developing avian retina. Dev. Biol 177, 160177.

Halfter, W., 1998. Disruption of the retinal basal lamina during early embryonic development leads to a retraction of vitreal end feet, an increased number of ganglion cells, and aberrant axonal outgrowth. J. Comp. Neurol 397, 89104.

Halfter, W., Deiss, S., Schwarz, U., 1985. The formation of the axo nal pattern in the embryonic avian retina. J. Comp. Neurol 232, 466480.

Halfter, W., Reckhaus, W., Kroger, S., 1987. Nondirected axonal growth on basal lamina from avian embryonic neural retina. J. Neurosci 8, 37123722 .

Henkemeyer, M., Orioli, D., Henderson, J.T., Saxton, T.M., Roder, J., Pawson, T., Klein, R., 1996. Nuk controls pathfinding of com missural axons in the mammalian central nervous system. Cell 86 , 3546

Higashijima, S., Nose, A., Eguchi, G., Hotta, Y., Okamoto, H., 1997. Mindin/F spondin family: novel ECM proteins expressed in the zebrafish embryonic axis. Dev. Biol 192, 211227.

Holash, J.A., Pasquale, E.B., 1995. Polarized expression of the recep tor protein tyrosine kinase Cek5 in the developing avian visual system. Dev. Biol 172, 683693 .

Holmes, G.P., Negus, K., Burridge, K., Raman, S., Algar, E., Yamada, T., Little, M.H., 1998. Distinct but overlapping ex pression patterns of two vertebrate slit homologs implies func tional roles in CNS development and organogenesis. Mech. Dev 79,5772

Holt, C.E., 1989. A single cell analysis of early retinal ganglion cell differentiation in Xenopus: from soma to axon tip. J. Neurosci 9, 31233145 .

Holt, C.E., Harris, W.A., 1993. Position, guidance, and mapping in the developing visual system. J. Neurobiol 24, 14001422

Hong, K., Hinck, L., Nishiyama, A., Poo, M., Tessier Lavigne, M., Stein, E., 1999. A ligand gated association between cytoplasmic domains of UNC5 and DCC family receptors converts netrin induced growth cone attraction to repulsion. Cell 97, 927941.
Hopker, V.H., Shewan, D., Tessier Lavigne, M., Poo, M.M., 1999. Growth cone attraction to netrin 1 is converted to repulsion by laminin 1. Nature 401, 6972.

Jean, D., Ewan, K., Gruss, P., 1998. Molecular regulators involved in vertebrate eye development. Mech. Dev 76, 318.

Johns, P.A., 1977. Growth of the adult goldfish eye. Part III: Source of the new retinal cells. J. Comp. Neurol 176, 343357.

Karlstrom, R.O., Trowe, T., Klostermann, S., Baier, H., Brand, M., Crawford, A.D., Grunewald, B., Haffter, P., Hoffmann, H., Meyer, S.U., Muller, B.K., Richter, S., Van Eeden, F.J.M., Nusslein Volhard, C., Bonhoeffer, F., 1996. Zebrafish mutations affecting retinotectal axon pathfinding. Development 123, 427 438

Keino Masu, K., Masu, M., Hinck, L., Leonardo, E.D., Chan, S.S.Y., Culotti, J.G., Tessier Lavigne, M., 1996. Deleted in Colorectal Cancer (DCC) encodes a netrin receptor. Cell 87, 175185.

Keller, S.A., Jones, J.M., Boyle, A., Barrow, L.L., Killen, P.D., Green, D.G., Kapousta, N.V., Hitchcock, P.F., Swank, R.T., Meisler, M.H., 1994. Kidney and retinal defects (Krd), a trans gene induced mutation with a deletion of mouse chromosome 19 that includes the Pax2 locus. Genomics 23, 309320.

Kennedy, T.E., Serafini, T., De la Torre, J.R., Tessier Lavigne, M., 1994. Netrins are diffusible chemotropic factors for commissural axons in the embryonic spinal cord. Cell 78, 425435 .

Kidd, T., Bland, K.S., Goodman, C.S., 1999. Slit is the midline repellent for the robo receptor in drosophila. Cell 96, 785794.

Kidd, T., Brose, K., Mitchell, K.J., Fetter, R.D., Tessier Lavigne, M., Goodman, C.S., Tear, G., 1998. Roundabout controls axon crossing of the CNS midline and defines a novel subfamily of evolutionarily conserved guidance receptors. Cell 92, 205215.

Kiss, J.Z., Rougon, G., 1997. Cell biology of polysialic acid. Curr. Opin. Neurobiol 7,640 646.

Krayanek, S., Goldberg, S., 1981. Oriented extracellular channels and axonal guidance in the embryonic chick retina. Dev. Biol 84, 4150

Laessing, U., Giordano, S., Stecher, B., Lottspeich, F., Stuermer, C.A.O., 1994. Molecular characterization of fish neurolin: a growth associated cell surface protein and member of the immu noglobulin superfamily in the fish retinotectal system with simi larities to chick protein DM GRASP/SC 1/BEN. Differentiation 56,2129

Laessing, U., Stuermer, C.A.O., 1996. Spatiotemporal pattern of reti nal ganglion cell differentiation revealed by the expression of neu rolin in embryonic zebrafish. J. Neurobiol 29, 6574.

Lang, D.M., Klisa, C., Warren, J.T., Stuermer, C.A.O. 1999 TAG 1 in the fish visual system: expression pattern and functional stu dies. Abstracts First European Meeting on Zebrafish Genetics and Development, 80 .

Lauderdale, J.D., Davis, N.M., Kuwada, J.Y., 1997. Axon tracts correlate with Netrin la expression in the zebrafish embryo. Mol. Cell. Neurosci 9, 293313.

Ledig, M.M., McKinnell, I.W., Mrsic Flogel, T., Wang, J., Alvares, C., Mason, I., Bixby, J.L., Mueller, B.K., Stoker, A.W., 1999a. Expression of receptor tyrosine phosphatases during development of the retinotectal projection of the chick. J. Neurobiol 39, 8196.

Ledig, M.M., Haj, F., Bixby, J.L., Stoker, A.W., Mueller, B.K., 1999b. The receptor tyrosine phosphatase CRYPalpha promotes intraretinal axon growth. J. Cell Biol 147, 375388.

Leonardo, E.D., Hinck, L., Masu, M., Keino Masu, K., Ackerman, S.L., Tessier Lavigne, M., 1997. Vertebrate homologues of C. ele gans UNC 5 are candidate netrin receptors. Nature 386, 833838.

Leppert, C.A., Diekmann, H., Paul, C., Laessing, U., Marx, M., Bastmeyer, M., Stuermer, C.A.O., 1999. Neurolin Ig domain 2 participates in retinal axon guidance and Ig domains 1 and 3 in fasciculation. J. Cell Biol 144, 339349.

Lilienbaum, A., Reszka, A.A., Horwitz, A.F., Holt, C.E., 1995. 
Chimeric integrins expressed in retinal ganglion cells impair pro cess outgrowth in vivo. Mol. Cell Neurosci 6, 139152.

Luckenbill Edds, L., 1997. Laminin and the mechanism of neuronal outgrowth. Brain Res. Rev 23, 127.

Mcdonald, R., Barth, K.A., Xu, Q., Holder, N., Mikkola, I., Wilson, S.W., 1995. Midline signalling is required for Pax gene regulation and patterning of the eyes. Development 121, 3267 3278 .

Macdonald, R., Wilson, S.W., 1996. Pax proteins and eye develop ment. Curr. Opin. Neurobiol 6, 4956

Matsunaga, M., Hatta, K., Nagafuchi, A., Takeichi, M., 1988. Guidance of optic nerve fibres by $\mathrm{N}$ cadherin adhesion molecules. Nature 334, 6264 .

McKerracher, L., Chamoux, M., Arregui, C.O., 1996. Role of lami nin and integrin interactions in growth cone guidance. Mol. Neurobiol 12,95 116 .

Ming, G.L., Song, H.J., Berninger, B., Holt, C.E., Tessier Lavigne, M., Poo, M.M., 1997. CAMP dependent growth cone guidance by netrin 1 . Neuron 19, 12251235.

Mueller, B.K., 1999. Growth cone guidance: first steps towards a deeper understanding. Annu. Rev. Neurosci 22, 351388.

Nornes, H.O., Dressler, G.R., Knapik, E.W., Deutsch, U., Gruss, P., 1990. Spatially and temporally restricted expression of Pax2 during murine neurogenesis. Development 109, 797809.

O'Leary, D.D.M., Wilkinson, D.G., 1999. Eph receptors and ephrins in neural development. Curr. Opin. Neurobiol 9,65 73 .

O'Leary, D.D.M., Yates, P.A., McLaughlin, T., 1999. Molecular development of sensory maps: representing sights and smells in the brain. Cell 96, 255269.

Ohta, K., Tannahill, D., Yoshida, K., Johnson, A.R., Cook, G.M., Keynes, R.J., 1999. Embryonic lens repels retinal ganglion cell axons. Dev. Biol 211, 124132

Orioli, D., Klein, R., 1997. The Eph receptor family: axonal gui dance by contact repulsion. Trends Genet 13, 354359.

Ott, H., Bastmeyer, M., Stuermer, C.A.O., 1998. Neurolin, the gold fish homolog of DM GRASP, is involved in retinal axon path finding to the optic disk. J. Neurosei 18, 33633372

Paschke, K.A., Lottspeich, F., Stuermer, C.A.O., 1992. Neurolin, a cell surface glycoprotein on growing retinal axons in the goldfish visual system, is reexpressed during retinal axonal regeneration. $\mathrm{J}$. Cell Biol 117, 863875 .

Peles, E., Nativ, M., Lustig, M., Grumet, M., Schilling, J., Martinez, R., Plowman, G.D., Schlessinger, J., 1997. Identification of a novel contactin associated transmembrane receptor with multiple domains implicated in protein protein interactions. EMBO J 16 , 978988.

Perron, M., Opdecamp, K., Butler, K., Harris, W.A., Bellefroid, E.J., 1999. X ngnr 1 and xath3 promote ectopic expression of sensory neuron markers in the neurula ectoderm and have dis tinct inducing properties in the retina. Proc. Natl. Acad. Sci. USA 96, 1499615001

Pierceall, W.E., Cho, K.R., Getzenberg, R.H., Reale, M.A., Hedrick, L., Vogelstein, B., Fearon, E.R., 1994. NIH3T3 cells expressing the deleted in colorectal cancer tumor suppressor gene product stimulate neurite outgrowth in rat $\mathrm{PC} 12$ pheochromocytoma cells. J. Cell Biol 124, 10171027.

Pollerberg, G.E., Beck Sickinger, A., 1993. A functional role for the middle extracellular region of the neural cell adhesion molecule (NCAM) in axonal fasciculation and orientation. Dev. Biol 156, 324340.

Pollerberg, G.E., Mack, T.G.A., 1994. Cell adhesion molecule SC1/ DMGRASP is expressed on growing axons of retina ganglion cells and is involved in mediating their extension on axons. Dev. Biol 165, 670687 .

Pourquie, O., Corbel, C., Le Caer, J. P., Rossier, J., Le Douarin, N.M., 1992. BEN, a surface glycoprotein of the immunoglobulin superfamily, is expressed in a variety of developing systems. Proc. Natl. Acad. Sci. USA 89, 52615265.

Ramon Y Cajal (1972) The Structure of the Retina (English edition). C.C. Thomas (Ed.), Springfield, IL., 148151.

Rathjen, F.G., Wolff, J.M., Frank, R., Bonhoeffer, F., Rutishauser, U., 1987. Membrane glycoproteins involved in neurite fascicula tion. J. Cell Biol 104, 343353.

Raymond, P.A., 1986. Movement of retinal terminals in goldfish optic tectum predicted by analysis of neuronal proliferation. J. Neurosei 6, 24792488

Redies, C., 1997. Cadherins and the formation of neural circuitry in the vertebrate CNS. Cell Tissue Res 290, 405413 .

Reichardt, L.F., Tomaselli, K.J., 1991. Extracellular matrix mol ecules and their receptors: Functions in neural development. Annu. Rev. Neurosci 14, 531570.

Riehl, R., Johnson, K., Bradley, R., Grunwald, G.B., Cornel, E., Lilienbaum, A., Holt, C.E., 1996. Cadherin function is required for axon outgrowth in retinal ganglion cells in vivo. Neuron 17, 837848.

Ruegg, M.A., Stoeckli, E.T., Kuhn, T.B., Heller, M., Zuellig, R., Sonderegger, P., 1989. Purification of axonin 1, a protein that is secreted from axons during neurogenesis. EMBO J 8, 5563 .

Rutishauser, U., Landmesser, L., 1996. Polysialic acid in the ver tebrate nervous system: a promotor of plasticity in cell cell inter actions. Trends Neurosci 19, 422427.

Sanyanusin, P., Schimmenti, L.A., McNoe, L.A., Ward, T.A., Pierpont, M.E., Sullivan, M.J., Dobyns, W.B., Eccles, M.R., 1995. Mutation of the PAX2 gene in a family with optic nerve colobomas, renal anomalies and vesicoureteral reflux. Nat. Genet 9,358364

Schlosshauer, B., Schwarz, U., Rutishauser, U., 1984. Topological distribution of different forms of neural cell adhesion molecule in the developing chick visual system. Nature 310, 141143

Schmitt, E.A., Dowling, J.E., 1996. Comparison of topographical patterns of ganglion and photoreceptor cell differentiation in the retina of the zebrafish, Danio rerio. J. Comp. Neurol 371, 222 234.

Scholes, J., 1979. Nerve fibre topography in the retinal projection to the tectum. Nature 278, 620624

Schulte, D., Furukawa, T., Peters, M.A., Kozak, C.A., Cepko, C.L., 1999. Misexpression of the Emx related homeobox genes cVax and mVax2 ventralizes the retina and perturbs the retinotectal map. Neuron 24, 541553

Sefton, M., Nieto, M.A., 1997. Multiple roles of Eph like kinases and their ligands during development. Cell Tissue Res 290, 243 250.

Serafini, T., Colamarino, S.A., Leonardo, E.D., Wang, H., Beddington, R., Skarnes, W.C., Tessier Lavigne, M., 1996. Netrin 1 is required for commissural axon guidance in the devel oping vertebrate nervous system. Cell 87, 10011014.

Serafini, T., Kennedy, T.E., Galko, M.J., Mirzayan, C., Jessell, T.M., Tessier Lavigne, M., 1994. The netrins define a family of axon outgrowth promoting proteins homologous to C. elegans UNC 6. Cell 78, 409424.

Sidman, R., 1961. In: Smelser (Ed.), Histogenesis of the Mouse Retina Studied with Tritiated thymidine. Academic Press, New York.

Silver, J., Sidman, R.L., 1980. A mechanism for the guidance and topographic patterning of retinal ganglion cell axons. J. Comp. Neur 189, 101111

Snow, D.M., Watanabe, M., Letourneau, P.C., Silver, J., 1991. A chondroitin sulfate proteoglycan may influence the direction of retinal ganglion cell outgrowth. Development 113, 14731485.

Stier, H., Schlosshauer, B., 1995. Axonal guidance in the chicken ret ina. Development 121, 14431454.

Stoeckli, E.T., Landmesser, L., 1998. Axon guidance at choice points. Curr. Opin. Neurobiol 8, 7379 . 
Strahle, U., Fischer, N., Blader, P., 1997. Expression and regulation of a netrin homologue in the zebrafish embryo. Mech. Dev 62, 147160 .

Stuart, E.T., Kioussi, C., Gruss, P., 1994. Mammalian Pax genes. Annu. Rev. Genet 28, 219236.

Stuermer, C.A.O., Bastmeyer, M., Bhr, M., Strobel, G., Paschke, K., 1992. Trying to understand axonal regeneration in the CNS of fish. J. Neurobiol 23, 537550.

Stuermer, C.A.O., Easter, S.S.J., 1984. Rules of order in the retino tectal fascicles of goldfish. J. Neurosci 4, 10451051.

Takeichi, M., 1990. Cadherins: a molecular family important in selective cell cell adhesion. Annu. Rev. Biochem 59, 237252.

Tanaka, H., Matsui, T., Agata, A., Tomura, M., Kubota, I., McFarland, K.C., Kohr, B., Lee, A., Phillips, H.S., Shelton, D.L., 1991. Molecular cloning and expression of a novel adhesion molecule, SC1. Neuron 7, 535545.

Taneja, R., Thisse, B., Rijli, F.M., Thisse, C., Bouillet, P., Dolle, P., Chambon, P., 1996. The expression pattern of the mouse receptor tyrosine kinase gene MDK1 is conserved through evolution and requires Hoxa 2 for rhombomere specific expression in mouse embryos. Dev. Biol 177, 397412.

Thanos, S., Bonhoeffer, F., Rutishauser, U., 1984. Fiber fiber inter action and tectal cues influence the development of the chicken retinotectal projection. Proc. Natl. Acad. Sci. USA 81, 1906 1910.

Torres, N., Gómez Pardo, E., Gruss, P., 1996. Pax2 contributes to inner ear patterning and optic nerve trajectory. Development 122 , 33813391.

Vielmetter, J., Lottspeich, F., Stuermer, C.A.O., 1991. The mono clonal antibody E587 recognizes growing (new and regenerating) retinal axons in the goldfish retinotectal pathway. J. Neurosci 11, 35813593

Viollet, C., Doherty, P., 1997. CAMs and the FGF receptor: an interacting role in axonal growth. Cell Tissue Res 290, 451455.

Walther, C., Gruss, P., 1991. Pax 6, a murine paired box gene, is expressed in the developing CNS. Development 113, 14351449.

Wanaka, A., Milbrandt, J., Johnson Jr., E.M., 1991. Expression of FGF receptor gene in rat development. Development 111, 455 468.

Warren, J.T., Chandrasekhar, A., Kanki, J.P., Rangarajan, R., Furley, A.J., Kuwada, J.Y., 1999. Molecular cloning and develop mental expression of a zebrafish axonal glycoprotein similar to TAG 1. Mech. Dev 80, 197201.

Wolfer, D.P., Henehan Beatty, A., Stoeckli, E.T., Sonderegger, P., Lipp, H.P., 1994. Distribution of TAG 1/Axonin 1 in fibre tracts and migratory streams of the developing mouse nervous system. J. Comp. Neurol 345, 132.

Wohrn, J.C.P., Puelles, L., Nakagama, S., Takeichi, M., Redies, C., 1998. Cadherin expression in the retina and retinofugal pathways of the chicken embryo. J. Comp. Neurol 396, 2038.

Xu, Q.L., Alldus, G., Madonald, R., Wilkinson, D.G., Holder, N., 1996. Function of the Eph related kinase rtk 1 in patterning of the zebrafish forebrain. Nature 381,319322 .

Yuan, W., Zhou, L., Chen, J. h., Wu, J.Y., Rao, Y., Ornitz, D.M., 1999. The mouse SLIT family: secreted ligands for ROBO expressed in patterns that suggest a role in morphogenesis and axon guidance. Dev. Biol 212, 290306.

Zisch, A.H., Stallcup, W.B., Chong, L.D., Dahlin Huppe, K., Voshol, J., Schachner, M., Pasquale, E.B., 1997. Tyrosine phos phorylation of L1 family adhesion molecules: Implication of the Eph kinase Cek5. J. Neurosci. Res 47, 655665. 